\title{
STUDI KASUS IMPLEMENTASI LATAR BELAKANG DAN RUMUSAN MASALAH DALAM BUKU WAWASAN AL-QUR'AN TENTANG AL-BALA' KARYA MARDAN
}

\section{Tammulis}

UIN Alauddin Makassar

E-mail: intankmuhlis@gmail.com

Achmad Abubakar

UIN Alauddin Makassar

E-mail: achmad.abubakar@uin-alauddin.ac.id

Muhsin Mahfudz

UIN Alauddin Makassar

E-mail: muhsinmahfudz@uin-alauddin.ac.id

\begin{tabular}{|c|c|c|}
\hline Received & Revised & Accepted \\
\hline 4 July 2021 & 2 Agustus 2021 & 20 September 2021 \\
\hline
\end{tabular}

\section{CASE STUDY ON IMPLEMENTATION OF BACGROUND AND FORMULATION PROBLEM IN THE BOOK OF AL-QUR'AN INSIGHT OF AL BALA OF MARDAN}

\begin{abstract}
This study aims to analyze the implementation of the background writing method and problem formulation in Mardan's book Insights al-Qur'an about al-Bala' by Mardan. There are two formulations of the problem: what is the epistemology of the background and the formulation of the problem? How is the implementation of "Background and Problem Formulation" in Mardan's book Insights of the Qur'an Against al-Bala' by Mardan? This type of research is library research, with the primary data source being the book Insights alQur'an about al-Bala' by Mardan. The study results indicate that the preparation of the background in the book Insights al-Qur'an about al-Bala' by Mardan has fulfilled three elements, namely the description of actual conditions, ideal conditions, and the importance of research. However, the importance of research is not stated directly in the background but is implied in the exposure of problematic conditions. As for the formulation of the problem formulation, three philosophical elements have been fulfilled, namely ontology, epistemology, and axiology

Keyword: bacground, problem formulation, Al-Qur'an insight, and al bala'.
\end{abstract}




\begin{abstract}
Abstrak
Penelitian ini bertujuan untuk menganalisis implementasi metode penulisan latar belakang dan rumusan masalah dalam buku Wawasan al-Qur'an tentang al-Bala' karya Mardan. Rumusan masalahnya ada dua yaitu bagaimana epistimologi latar belakang dan rumusan masalah? Bagaimana implementasi "Latar Belakang dan Rumusan Masalah" dalam buku Wawasan al-Qur'an Terhadap al-Bala' karya Mardan? Jenis penelitian ini adalah penelitian kepustakaan (library research) dengan sumber data primernya adalah buku Wawasan alQur'an tentang al-Bala' karya Mardan. Hasil penelitian menunjukkan bahwa penyusunan latar belakang dalam buku Wawasan al-Qur'an tentang al-Bala' karya Mardan telah memenuhi tiga unsur yaitu adanya gambaran kondisi ril, kondisi ideal dan pentingnya penelitian. Namun pentingnya penelitian tidak disebutkan secara langsung dalam latar belakang akan tetapi tersirat pada pemaparan kondisi problematika. Adapun perumusan rumusan masalahnya, telah terpenuhi 3 unsur filosofisnya yaitu ontologi, epistemologi dan aksiologi
\end{abstract}

Kata kunci: latar belakang, rumusan masalah, wawasan al-qur'an, dan al-bala'.

\title{
Pendahuluan
}

Sebuah ungkapan yang tidak asing bagi kalangan ilmuan yaitu "al-thari>qah ahammu min al-maddah" (metode lebih penting daripada materi pembahasan). Kebenaran ungkapan ini tentu tidaklah mutlak, namun bisa memberi gambaran betapa pentingnya menguasai suatu metode. Metode ibarat suatu jalan yang akan dilewati untuk samapai pada suatu tujuan yang direncanakan. Sehingga tanpa metode seseorang sulit mencapai tujuan yang dirancanakan itu. ${ }^{1}$ Seorang yang melakukan sebuah penelitian tanpa mengetahui metode penelitian ibarat orang yang memasuki hutan tanpa petunjuk arah

Dalam sebuah penelitian yang menjadi arah atau tujuan yang akan kita capai tertuang secara umum dalam judul/ topik penelitian yang dilahirkan dari munculnya suatu permasalahan yang di dapatkan oleh seorang peneliti, permasalalahan itu biasanya muncul ketika adanya ketidak sesuaian antar kenyataan yang terjadi dengan harapan. Namun dari topik itu untuk lebih fokusnya penelitian maka dirumuskanlah berberapa batasan masalah yang membatasi pembahasan terhadap suatu topik yang lebih umum, dengan kata lain bahwa rumusan masalah merupakan fokus utama penelitian, sehinga seornag peneliti tentunya akan merumuskan batasan masalah yang lebih spesifik dari suatu topik tertentu agar penelitiannya bisa lebih fokus.

Sehubungan dengan penjelasan di atas, maka kami akan mengadakan penelitian tentang hasil karya penelitian dari Bapak Mardan mengenai Wawasan alQur'an Tentang al-Bala Tentunya penelitian yang kami lakukan ini sangat besar manfaatnya disamping untuk memnuhi tugas kuliah, yang tidak kalah pentingnya merupakan suatu pemebelajaran bagi kami dengan melakukan penelitian pada karya tulis Bapak Mardan ini, tentunya akan menjadi sebuah pelajaran bagi saya khususnya tentang bagaimana menuangkan suatu metode kedalam sebuah karya tulis, terutama dalam menyusun latar belakang dan rumusan masalah.

${ }^{1}$ Nashruddin Baidan dan Ernawati Aziz, Metodologi Khusus Penelitian Tafsir (Yogyakarta: Pustaka Pelajar, 20019) h.1 


\section{Metode Penelitian}

Penelitian ini menggunakan penelitian kualitatif yang berbentuk library research (penelitian Pustaka). Jenis penelitiannya adalah deskriptif verifikatif. Penelitian ini dilaksanakan untuk menganalisis penerapan metode penulisan latar belakang dan rumusan masalah dalam buku Wawasan al-Qur'an tentang al-Bala' karya Mardan, dengan cara menganalisi metode yang ada pada latar belakang dan rumusan masalah dalam buku Wawasan al-Qur'an tentang al-Bala'kemudian membandingkan dengan pendapat para ahli seperti Nasruddin baidan, Ratna puspitasari dan lain lain, mengenai metode penulisan latar belakang dan rumusan masalah, kemudian menarik kesimpulan

\section{Hasil dan Pembahasan Epistemologi “Latar Belakang dan Rumusan Masalah”}

Latar belakang dalam bahasa Indonesia mengandung banyak konotasi, antara lain dasar (alasan) suatu tindakan (perbuatan); motif. Berdasarkan pengertian itu, maka yang dimaksud dengan 'latar belakang masalah/permasalahan' ialah kondisi atau situasi yang menyebabkan terjadinya permasalahan. Dengan kata lain, latar belakang masalah/permasalahan ialah motif yang menyebabkan fenomena atau fakta tersebut terjadi. ${ }^{2}$

Latar belakang masalah adalah suatu informasi yang disusun secara sistimatis berkenaan dengan fenomena dan permasalahan permasalahan yang menarik diteliti. Latar belakang dibuat untuk menjelaskan alasan mengapa suatu permasalaha akan diteliti, urgennya permasalahan itu dan pendekatan yang bisa digunakan untuk bisa menyelesaikan permasalahan itu. Latar belakang masalah dalam penelitian terdiri dari informasi tentang suatu masalah dan atau peluang permasalahan yang bisa ditindak lanjuti dengan penelitian, termasuk hal-hal yang melatar belakanginya. ${ }^{3}$

Rumusan masalah adalah hasil perumusan berbagai masalah yang telah dipilih dari berbagai asumsi perkiraan permasalahan yang diformulasikan dalam latar belakang penelitian sesuai ruang lingkup judul penelitian. jadi rumusan masalah itu lahir dari berbagai masalah masalah yang disebutkan dalam latar belakang yang kemudian dipilih beberapa masalah yang penting berdasarkan ruang linkup judul penelitian yang kemudian dirumuskan menjadi rumusan masalah yang akan diselesaikan. ${ }^{4}$

Menurut Sugiyono rumusan masalah dapat diartikan mencari jawaban dari suatu pertanyaan dengan cara mengumpulkan data dalam bentuk beberapa rumusan masalah berdasarkan penelitian. ${ }^{5}$

\footnotetext{
${ }^{2}$ Nashruddin Baidan dan Ernawati Aziz, Metodologi Khusus Penelitian Tafsir (Yogyakarta: Pustaka Pelajar, 20019) h.100

${ }^{3}$ Husain Umar, Metodologi Penelitian: Aplikasi dalam Pemasaran (Jakarta: Gramedia, 2001) h. 238

${ }^{4}$ Lihat, Nashruddin Baidan dan Ernawati Aziz, Metodologi Khusus Penelitian Tafsir (Yogyakarta: Pustaka Pelajar, 20019) h.86

5 Rina Hayati https://penelitianilmiah.com/rumusan-masalah/
} 


\section{Teori dan signifikansi “Latar Belakang dan Rumusan Masalah”}

Menurut Ratna Puspitasari latar belakang masalah merupakan informasi yang tersusun secara sistematis berkenaan dengan fenomena dan masalah problematik yang menarik untuk diteliti. ${ }^{6}$ Melihat apa yang disampaikan Ibu Ratna Pusoitasari tersebut, kita bisa memahami bahwa dalam latar belakang itu berisi paparan masalah masalah / penyimpangan yang bisa dilihat dari standar keilmuan yang ada, yang kemudian dilihat peluang yang dapat dipermasalahkan itu untuk dapat ditindak lanjuti lewat penelitian.

Adapun mengenai rumusan masalah, rumusan permasalahan dirumuskan berdasarkan latar belakang masalah, berbagai asumsi atau perkiraan permasalahan pemasalahan yang telah disebutkan dalam latar belakang kemudian dipilih beberapa permasalahan yang dapat diteliti sesuai judul penelitian dan kemampuan peneliti, kemanpuan peneliti yang dimaksud disini diantaranya kemampuan akademik, dana dan waktu yang tersedia. Kemudian dari permasalahan yang telah dipilih itulah dibuat rumusan masalah. ${ }^{7}$

Jadi jelas dari pembahasan di atas bahwa pada latar belakang digambarkan berbagai permasalahan permasalahan yang ada, namun rumusan masalah itu merupakan fokus pada permasalahan yang dipilih, sehingga rumusan masalah ini membatasi dan mempersempit ruang lingkup penelitian sehingga dapat lebih fokus pada titik permasalahan tertentu yang sesuai judul penelitian.

\section{Unsur-Unsur penting dalam "Latar Belakang dan Rumusan Masalah"}

Menurut Farida Hanum unsur unsur penting yang harus ada dalam latar belakang masalah adalah: ${ }^{8}$

a. Berisi paparan hasil pemikiran logis dan alasan alasan mengenai adanya ketidak sesuaian antara harapan dan kondisi yang terjadi

b. Dilakukan identifikasi berbagai pemasalahan secara umum yang kemungkinan bisa diselesaikan melalui penelitian.

c. Menjelaskan hal hal yang melatar belakangi sehingga penelitian itu penting dilakukan. Dengan kata lain penulis menuliskan berbagai alasan atau data yang menunjukkan kepada pembaca bahwa penelitian itu penting dan mendesak untuk diteliti

Untuk menyusun rumusan masalah ada beberapa unsur yang penting yang perlu diperhatikan sebagai berikut: ${ }^{9}$

a. Dibuat dengan kalimat tanya atau kalimat pernyataan yang menggambarkan permasalahan dengan jelas.

b. Ditulis dengan redaksi kalimat yang ringkas, padat dan mudah dipahami.

\footnotetext{
${ }^{6}$ Ratna puspitasari, Modul Latar Belakang Permasalahan dalam Penelitian oleh Ratna Puspitasari. Cirebon 19 September 2016

${ }^{7}$ Lihat, Nashruddin Baidan dan Ernawati Aziz, Metodologi Khusus Penelitian Tafsir (Yogyakarta: Pustaka Pelajar, 20019) h.86

${ }^{8}$ Hanum, Farida, and M. Si. "Strategi Penulisan Karya Ilmiah." (Yogyakarta: UNY (2003). h.8

${ }^{9}$ Nashruddin Baidan dan Ernawati Aziz, Metodologi Khusus Penelitian Tafsir (Yogyakarta: Pustaka Pelajar, 20019) h.100
} 
c. Harus berisi gambaran permasalahan yang mungkin diteliti, dijangkau nalar dan sesuai kemampuan peneliti dalam hal ini kemampuan akademik, biaya dan waktu yang ada.

Dari ketiga item unsur unsur perumusan masalah yang disebutkan di atas, cukup jelas; namun pada poin 3 perlu dijelaskan maksudnya.

Pertama: Permasalahan yang mungkin diteliti. Yang dimaksud disini yaitu objek penelitian adalah hal yang logis dan dapat diukur.

Kedua, kemamuan peneliti, yang perlu dijelaskan disini yaitu kemampuan akademik. Kemampuan akademik yang dimaksud disini adalah kecakapan akademik peneliti, Sı hanya dituntut mendeskripsikan ilmunya jadi tentu rumusan masalahnya hanya besifat mendeskripsikan permasalahan sementara $\mathrm{S}_{3}$ dituntut mampu menemukan sesuatu yang baru, sehingga dalam rumusan masalah dirumuskan dengan landasan ontologi, epistemologi dan aksiologi. Ontologi membahas bagaimana hakikat obyek yang ditelaah. Epistemologi membahas tentang bagaimana proses, wujud atau bentuknya. Dan aksiologi membahas tentang nilai yang berkaitan dengan kegunaan dari penelitian. ${ }^{10}$

\section{Studi Kasus Implementasi “Latar Belakang dan Rumusan Masalah” Dalam Buku Wawasan Al-Qur'an Terhadap al-Bala' Karya Mardan}

\section{Biografi Singkat Penulis}

Nama lengkap penulis adalah Mardan beliau lahir di Bululohe Maros, pada tanggal 12 November 1959. Anak dari pasangan suami istri bapak Samauna dan Ibu Bondeng. Penulis menempuh Pendidikan akademis mulai dari SDN Padangalla tamat tahun 1973, kemudian melanjutkan di PGAN 4 Tahun di Maros tamat tahun 1977 dan PGAN 6 Tahun di Maros tamat tahun 1980 dan Sarjana Lengkap Fakultas Adab tahun 1986 dan Master Agama (S2) pada PPS IAIN Alauddin tahun 1994 kemudian Doktor pada PPS UIN Alauddin 2007, selain Pendidikan akademis penulis jugan menempuh pendidikan Non Akademis yaitu Pesantren Maccopa dan Program Sandwich Mahasiswa S3 Tafsir PTAI Indonesia-Mesir selama 6 bulan. ${ }^{11}$

Adapun riwayat pekerjaan penulis, beliau merupakan dosen pada Fakultas Adab dan Humaniora UIN Alauddin sejak tahun 1989. Dia juga pernah menduduki jabatan sebagai sekretaris pada jurusan sejarah dan peradaban Islam tahun 19972000 dan juga pernah menduduki jabatan sebagai ketua Jurusan Bahasa dan Sastra Inggris tahun 2000-2004. Selain itu, pada tahun 2008-2012 beliau menjabat sebagai Dekan Fakultas Adab dan Humaniora. ${ }^{12}$

Beliau juga melakukan berbagai penelitian diantaranya:Inna wa Akhawa>tuha fi> Qawa>id al-Lughat al-'Arabiyyah, Al- Qiya $>$ m al- Bala'>ghiyyat fi Su>rat alMukmin, Konsepsi Keadilan dalam al-Qur'an, Perumpamaan (al-Amsa>l) dalam Perspektif al-Qur'an, Pengaruh Islam dalam Adat Perkawinan di Kecamatan Camba, Nilai- nilai Patriotisme Masyarakat Turatea dalam Menentang Imperialisme Belanda

10 Bahrum, Bahrum. "Ontologi, Epistemologi Dan Aksiologi." Sulesana: Jurnal Wawasan Keislaman 8.2 (2013): 35-36

${ }^{11}$ Mardan, Wawasan Al-Qur'an Tentang Al-Bala, h.456

${ }^{12}$ Mardan, Wawasan Al-Qur'an Tentang Al-Bala, h.456 
di Kabupaten Jeneponto, Penerapan Syari'at Islam di Sulawesi Selatan dalam Perspektif Budaya, Penafsiran Nabi saw Terhadap Kosakata al-Qur'an. Perumpamaan dalam al-Qur'an: Suatu Kajian Semiotik, Lingkungan Hidup dalam Perspektif al-Qur'an. Semiotik Perempuan dalam al-Qur'an dan Aktualisasi Pemberdayaannya. Naskah Klasik Islam Nusantara di Sulawesi Selatan, Naskah Nur al-Hadi: Lontara Bugis Makassar (Inventarisasi Koleksi dan Anotasi) Kitta' Saehetta Sopie : Deskripsi dan Anotasi ( Suatu Kajian dengan Pendekatan Filologi) dan Wawasan al-Qur'an tentang al-Bala. ${ }^{13}$

Selain aktif dalam meneliti penulis juga aktif menulis buku diantara buku hasil karya beliau adalah Dira $>$ sat fi $>$ 'Ulu $>m$ al-Qur'an, terbit pada tahun 2000 Dasar- dasar Ulu>mul Qur'an terbit 2001 dengan nomor ISBN: 979- 3267-06- 2 dan Ulu>mul Qur'an terbit tahun 2005 (Seri II) dengan ISBN: 979-3267-06-3. ${ }^{14}$

\section{Analisis Atas Teori Yang Dikembangkan Buku Wawasan al-Qur'an Tentang al- Bala' Karya Mardan}

Penelitian yang dilakukan Mardan ini, menggunakan metode Maudhui, hal ini sejalan dengan pengakuan Mardan dalam pembukaan tulisannya bahwa dalam penelitian ini, metode yang digunakan adalah metode tafsir tematik (maudhui). ${ }^{15}$ Dalam penelitian ini, lagkah langkah yang ditempuh Mardan, pertama menetapkan tema yaitu Wawasan Al-Qur'an Tentang al-Bala', kemudia mengumpulkan semua ayat ayat Al-Qur'an tentang bala' dan yang terkait dengan bala' seperti mushibah, fitnah, imtihan dan al-azab, kemudian menyusun tema pembahasan dengan kerangka yang sistematis kemudian mengelompokkan ayat ayat yang tepat sesuai tema dan kerangka yang dibuat, setelah itu ayat ayatnya dianalisis makna katanya (analisis kebahasaan), penempatan dan penggunaanya dalam al-Qur'an, korelasi atau munasbah dengan ayat sebelum dan sesudahnya, asbabun nuzulnya dilengkapi dengan hadis hadis yang relevan dengan pembahasannya sehingga ditemukan makna atau pemahaman tentang masalah tersebut dan menarik kesimpulan.

Muhammad Tulus Yamani menuliskan beberapa Langkah yang disebutkan Al-Farmawy dalam menerapkan metode maudhui yaitu sebagai berikut: ${ }^{16}$

a. Menentukan masalah yang akan dibahas

b. Mengumpulkan semua ayat yang terkait dengan masalah yang akan dibahas.

c. Menyusun ayat-ayat berdasar kronologi waktu turunnya atau sebab-sebab turunnya.

d. Menganalisis korelasi ayat-ayat tersebut dalam setiap surahnya masing masing.

e. Menyusun kerangka yang sempurna untuk melengkapi tema bahasan

f. Melengkapi pembahasan dengan hadis-hadis yang sesuai dengan pokok bahasan.

g. Mendalami ayat-ayat tersebut secara tematik dan menyeluruh dengan cara mengumpulkan ayat-ayat yang pengertiannya sama, atau mengkompromikan antara yang umum dan husus, yang mutlak dengan muqayyad, sehingga

\footnotetext{
${ }^{13}$ Mardan, Wawasan Al-Qur'an Tentang Al-Bala, h.457

${ }^{14}$ Mardan, Wawasan Al-Qur'an Tentang Al-Bala, h.457

${ }^{15}$ Mardan, Wawasan Al-Quran Tentang Al-Bala, h.421

16 Yamani, Muh Tulus. "Memahami Al-Qur'an dengan metode tafsir maudhu'i." J-PAI: Jurnal Pendidikan Agama Islam 1.2 (2015). h. 280-281
} 
semuanya bertemu pada suatu titik pemahaman, tanpa perbedaan atau pemaksaan dalam penafsiran.

h. Menyusun kesimpulan-kesimpulan tentang jawaban permasalahan yang dibahas menurut al-Qur'an.

Sehubungan dengan langkah langkah al-Farmawi yang disebutkan di atas dikaitkan langkah langkah yang diakukan Mardan dalam buku Wawasan al-Qur'an Tentang al-Bala', tampaknya langkah-langkah di atas sudah dilakukan namun masih terbatas, terutama pada poin 3 yaitu menyusun ayat-ayat menurut kronologi masa turunnya, belum nampak secara jelas dalam pembahasan, dan korelasi ayat-ayat dalam masing-masing surahnya ini juga masih terbatas pada beberapa ayat saja. Namun secara umum Mardan telah berhasil melakukan langka langkah penelitian secara maudhui sehingga mampu menjawab permasalahan tentang kesalahpahaman sebagian besar masyarakat Islam yang beranggapan bahwa bala' itu adalah keburukan mereka melaksanakan berbagai kegiatan tertentu dengan maksud untuk menolak bala' (kejahatan) dengan menggunakan ritual dan berbagai praktek kemusyrikan, padahal menurut hasil penelitian Mardan, bala' dalam al-Qur'an merupakan ujian yang diberikan Allah kepada manusia berupa tantangan hidup baik bentuk kelapangan maupun kesempitan hidup hal itu dimaksudkan agar manusia mencapainya suatu kehidupan yang baik, bahkan yang terbaik dan juga untuk mengetahui kualitas keimanan seseorang kepada Allah. ${ }^{17}$

Dalam buku Wawasan al-Qur'an Tentang al-Bala' disimpulkan bahwa al-Bala' dalam al-Qur'an merupakan ujian yang diberikan Allah kepada manusia berupa tantangan hidup baik bentuk kelapangan maupun kesempitan hidup hal itu dimaksudkan agar manusia mencapainya suatu kehidupan yang baik, bahkan yang terbaik dan dengan hal itu juga diketahui kualitas keimanan seseorang kepada Allah dalam realitas sosial. ${ }^{18}$

Dalam buku ini juga, Mardan menemukan perbedaan bala' dengan musibah dan fitnah, bala' menunjukkan pada hal yang baik dan buruk sementara musibah semuanya menunjuk pada hal yang tidak baik / negatif, sedangkan fitnah lebih banyak pada penderitaan hidup bisa berupa ujian di dunia dan siksaan diakhirat sementara bala' hanya digunakan untuk konteks kehidupan dunia. ${ }^{19}$

\section{Analisis Kritis atas "Latar Belakang dan Rumusan Masalah"}

Setelah membaca latar belakang yang ditulis Mardan pada buku yang berjudul "Wawasan al-Qur'an Tentang al-Bala", penulis memahami alur penulisan latar belakang tersebut dimulai dengan pemaparan al-Qur'an yang tidak mengalami perubahan, fungsi al-Qur'an sebagai petunjuk, sifat universal al-Qur'an yang harus dikaji, setelah itu beliau mengkaji makna kata bala' berdasarkan al-Qur'an dari berbagai dimensi, diantaranya dimensi spiritual, dimensi moral dan akhlak, dimensi etos-kerja, dimensi intelektual dan politik, dimensi sosio-historis, dimensi sosiologis, dimensi filosofis, dan dimensi psikologis dengan menyampaikan data data ayat alQur'an. Dari kajian makna bala' ditinjau dari berbagai dimensi itu, Mardan

\footnotetext{
${ }^{17}$ Lihat Mardan, Wawasan Al Qur'an Tentang Al-Bala, h 14

${ }^{18}$ Mardan, Wawasan Al-Qur'an Tentang Al-Bala, h.421

${ }^{19}$ Mardan, Wawasan Al-Quran Tentang Al-Bala h.421
} 
menyelipkan berbagai kondisi aktual yang terjadi dimasyarakat yang bertentangan dengan konsep bala' yang sebenarnya menurut al-Qur'an, misalanya pada pada dimensi sosiologi beliau menemukan ketidak sesuaian konsep al-Qur'an dengan pemahaman masyarakat, hal ini disebutkan pada paragrap pertama hal 14 bahwa terjadi kesalah pahaman masyarakat terutama di Sulawesi selatan dalam memahami bala', sehingga kadang kadang melakukan ritual ritual seperti kegiatan tolak bala dengan menggunakan mantra mantra yang tidak bersandar kepada Allah swt sehingga bisa mengantar kepada kemusyrikan. ${ }^{20}$

Selain yang dipaparkan di atas pada dimensi sosial-kultural serta politik, Mardan juga menemukan ketidak sesuaian pemahaman terhadap bala' dengan konsepsi al-Qur'an. Manusia memandang bala' dengan penilaian negatif pada hal dalam konsep al-Qur'an, bala' bisa berupa ujian untuk mencapai kehidupan yang lebih baik misalnya diberi sakit, agar dia tahu dan memahami nikmatnya sehat, diberi ketakutan agar mengetahui nilai keberanian, begitupula al-bala' berupa petaka, agar dirasakan makna kesabaran. ${ }^{21}$

Setelah mengidentifikasi berbagai masalah terkait dengan pemahaman tentang bala' kemudian Mardan menetapkan permasalahan pokok dalam penelitian ini, yakni "bagaimana Wawasan Al-Qur'an Tentang al-Bala. Sekaligus menetapkan sub-sub masalah untuk menjawab permasalahan pokok yang telah ditetapkan

Melihat alur dan isi latar belakang masalah yang ditulis Mardan tersebut di atas, dibandingkan dengan unsur unsur penting yang harus ada dalam latar belakang masalah yang dikemukakan Farida Hanum. Maka penulis berpendapat bahwa latar belakang tersebut telah telah memenuhi konsep penyusunan latar belakang yaitu ada situasi problematika (ketidak sesuaian antara realitas dan idealitas) yaitu ketidak sesuaian konsep bala' dalam al-Qur'an dengan beberapa realitas dalam kehidupan manusia. Dari problematika itulah dijelaskan/ diidentifikasi berbagai masalah. Pada latar belakang ini juga, memberikan suatu pemahaman akan pentingnya pengkajian tentang bala' ini, namun menurut penulis, Mardan tidak menyebutkan pentingnya penelitian ini secara tertulis pada latar belakang namun beliau menyampaikan tersirat pada pembahasan problematikanya, misalnya pada saat menjelasakan kesalah pahaman tentang tolak bala dengan menggunakan mantra-mantra atau kenduri dengan tidak menyandarkan segalanya kepada Allah, tetapi menggantungkan segalanya kepada selain Allah, termasuk menggantungkan diri kepada dukun-dukun tertentu dengan keyakinan dapat memberikan berkat, merupakan tindakan kemusyrikan, ${ }^{22}$ tentu penjelasan ini memberikan pemahaman bagi pembaca pentingnya pengkajian tentang bala ini, untuk memberikan pehaman kepada masyarakat supaya tidak melakukan ritual ritual tulak bala yang mengantar pada kemusyrikan. Namun menurut hemat penulis untuk lebih sistimatisnya dan memudahkan pemahaman pembaca, terutama bagi orang awam maka sebaiknya setelah menyampaikan berbagai permasalahan permasalahan yang ada harus menjelaskan secara jelas bagaimana pentingnya dan mendesaknya penelitian ini untuk segera dilakukan

\footnotetext{
${ }^{20}$ Lihat Mardan, Wawasan Al Qur'an Tentang Al-Bala, h 14-15

${ }^{21}$ Lihat Mardan, Wawasan Al Qur'an Tentang Al-Bala, h. 23

${ }^{22}$ Lihat Mardan, Wawasan Al Qur'an Tentang Al-Bala, h 14-15
} 
Selain yang saya sebutkan di atas dalam penulisan latar belakang ini, menurut hemat penulis, sebelum memasuki situasi permasalahan, terlalu Panjang pengantar ditarik kebelakang membahas tentang keotentikan al-Qur'an, fungsi fungsi alQur'an, dan keuniversalan al-Qur'an baru masuk pembahasan tentang situasi permasalahan tentang bala'. Jadi menurut pendapat penulis untuk efesiennya dan memudahkan memahami latar belakang sebaiknya langsung saja intinya tentang bala dan problematikanya.

Adapun mengenai rumusan masalah dalam buku Wawasan al-Qur'an tentang al-Bala'jika dibandingkan dengan konsep penulisan latar belakang menurut Nasruddin Baidan sebagaimana yang disebutkan di atas, menurut penulis tiga poin yang disebutkan Nasruddin Baidan yang harus ada dalam rumusan masalah semuanya telah terpenuhi dalam rumusan masalah yang ada pada buku Wawasan alQur'an Tentang al-Bala'. Berikut analisis penulis:

a. Dibuat dengan kalimat tanya atau kalimat pernyataan yang menggambarkan permasalahan dengan jelas. ${ }^{23}$ Hal ini sudah terpenuhi karena dalam rumusan masalah, Mardan menyusun rumusan masalah dalam bentuk kalimat pernyataan yang jelas menggambarkan permasalahan

b. Ditulis dengan redaksi kalimat yang ringkas, padat dan mudah dipahami. ${ }^{24} \mathrm{Hal}$ ini juga terpenuhi, melihat rumusan masalahnya mudah dipahami, singkat, padat dan akurat.

c. Harus berisi gambaran permasalahan yang mungkin diteliti, dijangkau nalar dan sesuai kemampuan peneliti dalam hal ini kemampuan biaya, waktu dan kemampuan akademik ( S1 dan S2 hanya dituntut mendeskripsikan ilmunya jadi tentu rumusan masalahnya hanya besifat mendeskripsikan permasalahan sementara S3 dituntut mampu menemukan sesuatu yang baru, sehingga dalam rumusan masalah dirumuskan dengan landasan ontologi, epistemologi dan aksiologi). ${ }^{25}$ Untuk hal ini rumusan masalah yang ditulis Mardan sudah menggambarkan sesuatu permasalahan yang mungkin diteliti dan terjangkau oleh nalar, begitu pula filosofis penyusunannya rumusan masalah dirumuskan dengan landasan ontologi, epistemologi dan aksiologi.

Jadi Penulis menyimpulkan bahwa rumusan masalah yang dalam buku Wawasan al-Qur'an tentang al-Bala'sudah memenuhi teori penulisan rumusan masalah sebagaiman yang disebuatkan Nasruddin Baidan, semua poin poinnya terpenuhi dengan baik, cuma menurut hemat penulis poin-poin rumusan masalahnya terlalu banyak, jadi sebaiknya poinya dipersempit menjadi dua atau tiga poin saja yang bisa memuat semua poin poin itu.

\footnotetext{
${ }^{23}$ Nashruddin Baidan dan Ernawati Aziz, Metodologi Khusus Penelitian Tafsir, h.100

${ }^{24}$ Nashruddin Baidan dan Ernawati Aziz, Metodologi Khusus Penelitian Tafsir, h. 100

${ }^{25}$ Nashruddin Baidan dan Ernawati Aziz, Metodologi Khusus Penelitian Tafsir, h.100
} 


\section{Simpulan}

Latar belakang masalah adalah informasi yang tersusun secara sistimatis berkenaan dengan fenomena dan masalah problematik yang menarik untuk diteliti. Sehingga dalam latar belakang minimal tiga unsur harus ada yaitu gambaran kondisi ril, kondisi ideal dan pentingnya penelitian. Sedangkan pada rumusan masalah dirumuskan bersifat filosofis dan radikal karena mahasiswa pada level $\mathrm{S}_{3}$ harus mampu menemukan sesuatu yang baru, sehingga dalam rumusan masalah dirumuskan dengan landasan ontologi, epistemologi dan aksiologi

Berdasarkan analisis penulis terhadap buku Mardan, penulis berkesimpulan bahwa penyusunan latar belakang dalam buku tersebut telah memenuhi tiga unsur (gambaran kondisi ril , kondisi ideal dan pentingnya penelitian) namun pentingnya penelitian tidak disebutkan secara langsung dalam latar belakang namun tersirat pada pemaparan kondisi problematika. Adapun perumusan rumusan masalahnya, telah terpenuhi 3 unsur filosofisnya (ontologi, epistemologi dan aksiologi).

Dalam malakalah ini dilakukan analisis terhadap latar belakang masalah dan rumus masalah, diharapkan teori teori tentang penyusunan latar belakang masalah dan rumusan masalah dapat diterapkan dalam penulisan karya karya ilmiah selanjutnya, dan sangat penting untuk dilakukan analisis pada bagian bagian lain dari karya ilmiah ini sebagai bentuk pembelajaran dalam menulis karya ilmiah

\section{DAFTAR PUSTAKA}

Bahrum, Bahrum. "Ontologi, Epistemologi Dan Aksiologi." Sulesana: Jurnal Wawasan Keislaman 8.2 (2013)

Baidan, Nashruddin dan Ernawati Aziz, Metodologi Khusus Penelitian Tafsir, Yogyakarta: Pustaka Pelajar, 2019

Hanum, Farida, and M. Si. "Strategi Penulisan Karya Ilmiah." (Yogyakarta: UNY (2003).

Mardan, Wawasan Al-Qur'an Tentang Al-Bala/ Malapetaka, Jakarta 2008

Puspitasari, Ratna, Modul Latar Belakang Permasalahan dalam Penelitian, Cirebon 19 September 2016

Rina Hayati https://penelitianilmiah.com/rumusan-masalah

Sugiyono. 1999. Metode Penelitian Bisnis. Bandung: Alfabeta

Umar, Husain, Metodologi Penelitian: Aplikasi dalam Pemasaran, Jakarta: Gramedia, 2001. 